\title{
MEASURING WEBSITE QUALITY OF THE INDIAN RAILWAYS
}

\author{
RAJESH KUMAR JAIN ${ }^{1}$, SANTOSH RANGNEKAR ${ }^{2}$ \\ ${ }^{1}$ Sr. Associate Professor, Institute of Management, Nirma University \\ ${ }^{2}$ Head Department of Management, IIT Roorkee
}

\begin{abstract}
Websites are being widely used for commercial purpose in both private and public sectors. Whether such widespread use and dependency on web enhances the satisfaction among its users or not is to be understood. The objective of the present study is to examine and analyze the quality of the website of the Indian Railways.

The Indian Railways website quality was compared with a perceived ideal website. The attributes for assessing the website quality of a railways were developed on the basis of pertaining literature review, interview with some of the web site users and with personal observations. In the present study the mean value in case of the Indian Railways is 36.28 and in case of perceived ideal website the mean value is 45.06. The F-statistic value is 52.75. The result allows us to infer that the Indian Railways website quality is not on the mark compared to what the users expect in a perceived ideal website.
\end{abstract}

The implication of the present study is that the Indian Railways should focus on the quality of its website for increased user satisfaction and for enhancing its image.

\section{KEY WORDS}

Website Quality, Indian Railways, Users Perception, Evaluation.

\section{INTRODUCTION}

Quality can be defined in many ways depending on what product or service it is related with or who i.e. customer, or producer is defining it. The American Society for Quality defines quality as a subjective term for which each person has his or her own definition. In technical usage, quality can have two meanings: the characteristics of a product or service that bear on its ability to satisfy stated or implied needs, and a product or service free of deficiencies.

Indian Railways, a premier public sector enterprise of the country is the largest rail network in Asia and the worlds' second largest network of employees under the one management. Indian Railways is a multi-gauge, multi-traction system covering a total of $108,706 \mathrm{~km}$ of track. This track includes $86,526 \mathrm{KM}$ route of broad gauge $(1676 \mathrm{~mm})$ line of which $16,001 \mathrm{~km}$ has been electrified. It has $18,529 \mathrm{~km}$ of meter gauge $(1000 \mathrm{~mm})$ line, and 3,651 km of narrow gauge $(762 / 610 \mathrm{~mm})$ line.

Indian Railways runs around 11,000 trains everyday, of which 7,000 are passenger trains. It has 7566 locomotives, 37,840 coaching vehicles, 222,147 freight wagons, 6853 Stations, 300 Yards, 2300 Good sheds, 700 Repair shops, and 1.54 million work forces. 
A government holding enterprise, Indian Railways is all set to compete with the private players in the airlines sector. Private airlines like Deccan Airlines have already announced that their competition is not with the other airliners in the country but with the Indian Railways. The Indian Railways Catering and Tourism Corporation has launched an on-line ticketing facility which can be accessed through its website www.irctc.co.in. Presently this facility is available at 758 locations in the country covering about $96 \%$ of the total workload of passenger reservation. Keeping the trend alive the Indian Railways through its associate www.irctc.com has also started, on a pilot basis an Interactive Voice Response System at 98 stations.

Through its own intra-net "Railnet" it has networking between Railways Board, Zonal Headquarters, Divisional Headquarters, Production Units, and Training Centres etc. At the International level, Indian Railways construction division is executing different projects in Malaysia, Bangladesh, and Indonesia.

Of the 13 million passengers served by the network everyday, nearly 12 million are unreserved passengers. To cater to this huge segment, computer based ticketing system has been launched for all stations in Delhi area and it is reported that in due course it will be launched throughout the country. With this, unreserved tickets can be issued even from locations other than the boarding station and will reduce crowds at booking offices and stations. A pilot project for issuing monthly and quarterly season tickets through Automated Teller Machines has also been launched in Mumbai last year and has been found to be very successful. Another pilot project for purchasing tickets including monthly and quarterly season tickets through Smart Card has been launched by Indian Railways.

Rail Tel Corporation has been created to make a nationwide broadband multimedia network by laying optical fiber cable along the railway tracks. Optical Fiber based communication system will further improve Indian Railways telecommunication systems. Optical fiber cable lying has increased to 7,700-route kilometer last year. This system will provide better operational and passenger amenities and additional revenue to Indian Railways.

The Internet is offering customers and businesses an altogether new way of transacting. It's a new and very powerful channel, through which customers are coming closer to businesses. Everyday more and more people are joining this networked world. However some of the Websites give a very good experience of using while some other cause frustration, which results in dissatisfaction among the users. Tolerance level for poor quality on the web of the people is decreasing day by day. Collett \& King (1999) demonstrate that nearly $78 \%$ of the online shoppers never make it to the checkout line. Getting customers to the website of a company is one thing, making them to purchase is just another. Avery (2000) reported that the quality and the usability of the site determine the turning of visitors into buyers. He notes that the Web quality and usability are key factors in differentiating companies doing business on the Web - for every dissatisfied customer who complains, there are nine who leave the site, shop somewhere else and tell ten other people about their bad experience. Companies must address issues of quality and usability on their sites, this will help in ensuring customers return to Websites.

If a Website is going to be one of the important sales channels, then it is imperative that the companies must address the concerns of Website quality. It is necessary to identify what the customers expect from a Website. Ignoring this dimension of Website requirement may lead to decreased customer satisfaction. The present study is an effort in this direction. The objective of the study is to evaluate the Website quality of Indian Railways. 


\section{OTHER RELATED STUDIES}

Much research has been conducted which has discussed and proposed measures to evaluate Websites, measures ranged from number of hits (Jaspersen, 1996); server log analysis (Murphy, 1999), usability of Website (Nielsen and Norman, 2000); user satisfaction (Stevenson et al., 2000). Websites service quality measurement has also been addressed through WebQual (Barnes and Vidgen, 2000), WebQual ${ }^{\mathrm{TM}}$ (Loiacono et al., 2002) and E-Qual (Kaynama and Black, 2000). These studies involved an examination of literature and exploratory research to identify elements of service important in Website from consumers' perspective. Stressing the importance of users requirement for the organizations, Sweeney and Lapp (2004) writes 'understanding consumer perceptions of the Website experience, such that consumers can contribute to the firm's productivity and simultaneously enhance their own outcomes is vital for managers'. They further noted that the value of Website is not recognized at al unless the Website meets some basic standards. These include up to date information, working of links, speed of loading, degree of control, and search across Web pages within a Website.

Chang and Arnett (2000) identified factors associated with website success in the context of electronic commerce. The factors identified were information and service quality, system use, playfulness, and system design quality. Their propositions were a.) Organizations should seek ways to improve information and service quality provided through Websites; b.) Customers rather than the organizations should control the on-line transaction process. c.) Cultivate hedonic pleasures in the website by motivating customers to participate, promoting customer excitement and concentration, and including charming features to attract customers and to help them enjoy the visit; d.) System design quality have direct relationship with website success.

Zeithmal et al. (2001) reported 11 dimensions for electronic service quality based on focus-group research with customers who shop on the Internet; these are mentioned in the Appendix. Russell and Taylor III (2003) conceptualized 10 dimensions of web site quality; these are also mentioned in the same appendix. In Indian context one of the leading offshore developers e-Zest Solutions evaluates Websites based on ten different aspects of each site. These include purpose, functionality, download time, ease of navigation, usefulness of content, overall graphic presentation, ease of contact and responsiveness, online catalogue, secure payment processing, and effectiveness of marketing. In Indian context no study could be found which has tried to evaluate the quality of a Website keeping in mind user's experience.

\section{METHODOLOGY}

\subsection{Data Collection}

The Indian Railways Website quality was compared with a perceived ideal Website. Respondent's expectations were captured with regard to their perceptions of an ideal Website quality and their actual experiences of accessing the Indian Railways Website. The attributes for assessing the Website quality of Indian Railways were developed on the basis of pertaining literature review, interview with Website users and with personal observations. A framework was developed for understanding customer satisfaction with users of Websites. A total of 62 respondents, users of 
Websites were selected randomly. Respondents included were drawn from various organizations, industries, age groups, and occupations. All variables in the survey were measured on a five point Likert scale from 5 (Most important) to 1 (Least important).

\subsection{Data Analysis and Results}

Responses obtained were statistically tested for their significance. One-way ANOVA was applied to analyze the data. F-test gave the following result, as shown in the table below.

\section{Table 1 Single Factor ANOVA}

\begin{tabular}{|c|c|c|c|c|}
\hline Groups & Count & Sum & Average & Variance \\
\hline Ideal Website & & 2794 & 45.06452 & 28.32364 \\
\hline Indian Railways & 4 & 1778 & 36.28571 & 54.79167 \\
\hline
\end{tabular}

\begin{tabular}{lrrrrrr} 
ANOVA & \multicolumn{1}{c}{ MS } & \multicolumn{1}{c}{ F } & P-value & F crit \\
\hline \multicolumn{1}{c}{ Source of Variation } & \multicolumn{1}{c}{ SS } & df & \multicolumn{1}{c}{ MS } & \\
\hline Between Groups & 2109.285 & 1 & 2109.285 & 52.75945 & $5.94 \mathrm{E}-11$ & 3.928193 \\
Within Groups & 4357.742 & 109 & 39.97928 & & & \\
& & & & & & \\
Total & 6467.027 & 110 & & & & \\
\hline
\end{tabular}

The ANOVA test above shows the significance of the differences in the two groups. At a very small 'p' value (of 5.94E-11), the null hypothesis that there is no significant difference between the Ideal and Railways Website quality is rejected. In other words as is clear by the observed ' $F$ ' value of 52.75, which is bigger than the critical ' $F$ ' value (of 3.92), there lies a statistically significant difference in the Indian Railways and Ideal Websites.

\section{DISCUSSION}

The items in the questionnaire included were Continuous Connectivity, Quick Response and Help Whenever Needed, Ease of Access, Options to Pay, Buy, \& Search, Content Usefulness, Ease of Navigation, Simple to Use and Properly Structured, Confidence \& Clarity of Data Generated, Privacy \& Security of User, Aesthetics, and Customization/Personalization. Out of the 11 dimensions of Website quality reported by Zeithmal et al. (2001) the dimensions which are common are Quick Response and Help whenever Needed, Ease of Access, Options to Pay, Buy, and Search, Ease of Navigation, Privacy and Security of User, Aesthetics, and Customization/Personalization. We additionally found Continuous Connectivity, Content Usefulness, Simple to Use and Properly Structured, Confidence and Clarity of Data Generated as important attributes of Website quality. Russell and Taylor III (2003), additionally reported Server Reliability, Speed of Page Loading, Transaction Time, and Domain Name as important determinants of Website quality. The employee-related dimension of service quality, which is important for excellent service quality, does not exist on the Internet; this becomes an advantage of the Internet, because consistency of service is almost ensured. However, it also requires that the potential for problems be eliminated because there is no helpful, well-trained employee immediately available to correct the situation. 
The result of the study rejects the null hypothesis of no difference of Website quality of Indian Railways compared to an ideal Website. The ideal Website average value of 45.06 is greater than the Indian Railways Website average value of 36.2 (Table 1), that shows Website quality of Indian Railways is statistically significantly lower. The Indian Railways Website scores high on confidentiality and maintaining the privacy/security of users, however for an ideal Website there are more important dimensions like clarity of data produced, quick response, content usefulness, continuous connectivity, simple to use and properly structured, and ease of accession. Chang, (2000) also reported that security is only a necessary condition but not a sufficient condition of designing a successful website: a secure Web market does not guarantee customers. A successful website is one that attracts customers, makes them feel the site is trustworthy, dependable, and reliable and guarantees customer satisfaction. Therefore it can be concluded that secured transaction is a pre-condition for transacting through a website.

\section{CONCLUSION}

If more and more Indian Railways customers use Website for their ticketing related works then it would be beneficial to the Railways as it would be saving in the cost of printing of stationeries for both reservation ticket and application form printing. Occasionally it was found that the Indian Railways front side staff is busy so if its Website takes on some customer contact related work then the customer service would increase and thereby relieving some of the front-end employees work.

If because of some reason the site takes time for processing the request then there should be a clear message informing the browsers for the same. Like some of the Indian airliners, Indian Railways should provide the facility of multiple itineraries planning in its Website. Codenames of all the stations should be provided rather than of only bigger stations. Messages like "station code is invalid" etc. frustrates the browser. Unless the enquired station is a starting station it is very difficult to get the connecting train schedule. It is revealed during the survey that sometimes it takes the whole day to plan an itinerary. In the course of accessing the Indian Railways Website one frequently gets the message "Unable to retrieve due to communication failure". After receiving this message if the request is resubmitted then there is no indication whether the request is being reconsidered and processing is on or nothing is happening. For messages like "Could not retrieve trains list.... selected class has no trains", the Website should give an option to change the class or any other selected field, before automatically resetting the window all over again. At times it becomes highly confusing when Website returns the message "Class is not available" for the unavailability of train on a particular day.

Additionally as this survey has demonstrated that there should be a mechanism in place to monitor the satisfaction of Indian Railways Website users. Any dissatisfaction if at all there in users of Website should be seriously addressed to. Though ticketing through Web is an added facility in the form of new channel and has nothing to do with the main function of providing transportation utility to its customers but as the survey suggests people expect reasonably good browsing experience. Moreover Websites provide an opportunity for enhancing service quality therefore Indian Railways should continuously strive to find ways to improve quality of its Website. It is not enough to register Web presence in today's networked environment, but as the study suggests quality Web service and experiences during the Web encounter are equally important. Certainly Railways should enhance the quality of its Website by considering the relevant attributes and also increase the awareness among its customers so that more and more people use its Website for their ticketing and other travel concerning work. This will help Indian Railways to provide a better experience to its customers and that too without incurring much additional cost. 


\section{LIMITATIONS}

Although these results provide some important insights about the customer satisfaction and contents, continual monitoring of the development and functionality of Websites will be needed. The data presented should be enlarged both cross-sectional and longitudinally for having a better picture of dynamics of Web-enabled ticketing. The sample frame used for this study may not necessarily be representative of all the Website users. Also there may be some quality attributes other than those included in this study that vary in importance, which may be associated with distinct motivations and experiences in Website usage. Therefore the needs of different user groups in terms of their extent of desired involvement with Websites need to be identified. Hence future research need to explore these aspects. Also the electronic marketplace on the Web in India is not yet much popular and hence there is a limited knowledge for consumers as to how to pursue electronic ticketing activities on the Web.

\section{REFERENCES}

Avery Jim, (2000), Business 2.0, March, 2000 downloaded from http://www.baldrigeplus.com/Newsletter_Supplement_2.html.

Barnes, S. and Vidgen, R. (2000), "WebQual: an exploratory study of Web site quality", paper presented at the European Conference on Information Systems, Vienna, 3-5 July.

Chang Liu, Arnett P. Kirk, (2000), "Exploring the factors associated with Website success in the context of electronic commerce" Information \& Management, Vol.38 pp. 23-33.

Collett Stacy and King Julia (1999), Why Online Browsers Don't Become Buyers, http://www.computerworld.com/printthis/1999/0,4814,37749,00.html, downloaded 01/16/06, archived 2015.

Indian Railways Website http://www.indianrail.gov.in, and http://www.irctc.co.in, (accessed on 03.06.2015)

Jaspersen, T. (1996), "Erfolgskontrolle von Online-Marketing-Aktivitaten-'Hitliste"”, Absatzwirktschaft, Vol. 12, pp. 46-8.

Kaynama, S.A. and Black, C.I. (2000), “A proposal to assess the service quality of online travel agencies: an exploratory study", Journal of Profesonal Services Marketing, Vol. 21 No. 1, pp.6388 .

Loiacono, E.T., Watson, R.T. and Goodhue, D.L. (2002), Winter Marketing Educators' Conference, Austin, Texas, American Marketing Association, New York, NY, pp. 432-8. 
Murphy, J. (1999), "Surfers and searchers", Cornell Hotel and Restaurant Administration Quarterly, April, pp.84-95.

Nielsen, J. and Norman, D.A. (2000) "Website usability: usability on the Web isn't a luxury", Information Week Online, 14 January, available at: http://www.informationweek.com/773/web2.htm (accessed 16 February, 2006; archived in 2015).

Stevenson, J.S., Burner, G.C. II and Kumar, A. (2000), "Webpage background and viewer attitudes", Journal of Advertising Research, Vol. 40, January-April, pp. 29-34.

Sweeney C. Jillian and Lapp Wade (2004), "Critical service quality encounters on the web: an exploratory study”, Journal of Services Marketing, Vol. 18, No. 4, pp.276-289.

Zeithaml, Valarie A., Parsuraman, A. and Arvind Malhotra, (2001), "A conceptual framework for understanding e-service quality implications for future research and managerial practice", Marketing Science Institute, Report Summary, 00-115, pp. 14.

\section{APPENDIX}

e-Service Quality (e-SQ) dimensions by Zeithaml et al. (2001)

\section{Access}

Ease of Navigation

Efficiency

Flexibility

Reliability

Personalization

Security / Privacy

Responsiveness

Assurance / Trust

Site Aesthetics

Price Knowledge

\section{Quality attributes specific to Web site service (Russell and Taylor III, 2003)}

Ease of Use

Clarity of Information and Instructions 
Server Reliability

Speed of Page Loading

Transaction Time

Aesthetics

Privacy and Security

Domain Name

Human Backup

Transaction Reliability 